\title{
On the Silk Road Discovery Zoroastrianism Temple in the Edge of The Yangtze River
}

\author{
Zamotaeva Kristina, Kring Kristall \\ Challenge College, wuxue city, Hubei Province, China 435416
}

Key words: The Silk Road, Zoroastrianism, The Kaffa Temple, Challenge College

\begin{abstract}
Zoroastrianism temple is located at the Wuxue City, Hubei Province. Emperor yangdi of the sui dynasty himself set up the Zoroastrianism temple. Leader of temple is Mr Huiyuan. It is chief magua or mobed. Mr.Daoxin is Lord of the Temple or Bagnapet . Huiyuan's pure land sect and zen Buddhism originated in Zoroastrianism temple . Tao_yuanming, who founded the white lotus religion. The liang dynasty made the worship of the fire in the sea with the worship of the ancient road of the tea horse and the ancient turkic people. For the first time, the author put forward a visit to the temple of the far east, which is located in Kaffa temple. Tao_yuanming, the prince of zhaoming, Miss Mage was born in the Kaffa district; The new ideas of kaffa are published in the

《book of the zhaoming》 and painting. The author adopted the archaeological cultural relics of the ancient calligraphy and painting and historical documents than method, obtained the Zhou's visit to the marriage TaoKan son, shaw, the queen mother in Kaffa Turkic countries, Mago offer longevity in Kaffa (kuangshan) the Great Wall and other conclusions. Broadcasting second, the author discusses the information the calligraphy and painting, not much.i historical mystery, ajay genealogies, specifically through checked according to the family context to visit the graveyard, epitaph, obtained kaffa mountain (shu, Qi, guang, huang) during the southern song dynasty belongs to the conclusion of local warlords. The south of the Yellow River, north of the Yangtze river, is neither a Golden state nor a Song dynasty. It also points out that the 《Book of Calligraphy and Painting》, which is written by 齊, has been linked to the movement of the peng's movement. Third, the study of Zoroastrianism general method was conducted through the excavation of cultural relics, the author to browse through broadcasting the information the 《Book of Calligraphy and Painting $》$, to study the Zoroastrianism, and achieved initial results.
\end{abstract}

\author{
丝绸之路上拜火教 \\ 远东教廷遗址江州匡山寺九考 \\ 扎莫塔耶娃. 克丽斯季娜; 彭金火. 彭达 \\ 沧浪书院 \\ 武穴市，湖北省，中国 435416
}

关键词：丝绸之路，拜火教，江州匡山寺，沧浪书院

中文摘要：拜火教远东教廷遗址江州匡山寺位于湖北省武穴市匡山旅游风景区、先秦两汉庐 江郡寻阳县石城遗址上。隋炀帝亲自筹建了江州匡山寺。匡山惠远担任拜火教五品官萨宝。 妖人员道信官位拜火教祅正为七品。惠远的净土宗与道信的禅宗都起源于江州匡山寺。陶渊 明把昭武九姓粟特人拜火教与寻阳五水蛮狼狗图腾盘瓠信仰融合在一起, 创立了匡山白莲 
教。岛夷梁朝萧氏把海上传来的拜火教与茶马古道突厥人陆地上传来的拜火教融合在一起, 形成了江淮特色的拜火教。作者首次提出了拜火教远东教廷遗址位于江州匡山寺; 陶渊明、 昭明太子、麻姑出生于匡山地区; 《昭明文选》、《宣和书画谱》成书于匡山的新观点。作 者采用了传世书画与历史文献考古文物比对的方法, 得出了寻阳周访联姻陶㑆, 萧太后突厥 汗国于匡山, 麻姑献寿于匡山长城等结论。其次, 作者针对《宣和书画谱》没有著作人的历 史疑案, 专门翻阅查验了《彭氏宗谱》, 按照家谱脉络实地查看墓地, 对照墓志铭, 得出了 匡山地区（舒、详、光、黄）在南宋期间属于地方军阀割据的结论。黄河以南、长江以北, 既不属于金国又不属于宋朝, 独立建国为 “齊”。也指出了齊国编写的《宣和书谱》和《宣 和画谱》的流传, 与匡山彭氏迁徙有关。第三, 研究拜火教一般方法是通过考古挖掘文物来 进行的, 作者另辟蹊径, 通过翻阅《宣和书画谱》来研究拜火教, 且取得初步成果。

\section{1. 引言}

隋炀帝统一中国后, 确定了拜火教（祅教）的国教地位，在江州寻阳县石城县治创建了 拜火教远东教廷--江州匡山寺。智者大师主持全国拜火教宗教事务。上自两汉魏晋下止北 宋, 汉武帝元封五年到宣和二年, 公元前 106 年到公元 1120 年, 江州匡山寺的建筑物或毁 于战火, 或毁于朝廷灭佛, 江州匡山寺的高僧和居士创作了一千多幅书法和绘画作品, 在宣 和二年汇集成册出版为《宣和书谱》和《宣和画谱》。《宣和书画谱》通过书画艺术形式真 实再现了江州匡山寺 1226 年间的拜火教远东教廷建筑风格、祭司仪式、人物形象、历史事 件。

\section{2. 陶渊明藉贯匡山考}

匈奴天神金人曰佛、匈奴君王禅于曰禅。汉武帝寻阳浮江，白匈奴剿淮南王。淮南江 北，佛寺禅房。

石虎麻胡秋控江襟淮，后赵白胡麻衣仙姑释道灵泉洞。两晋流民南迁五溪水，昭武九姓 东征彭蛍湖。

盘瓠蛮溪族陶㑆定居庐江郡寻阳县, 汝南人周访嫁女㑆子瞻。郭默杀刘胤、陶㑆杀郭 默、苏峻杀陶瞻。访嫡孙周强，强生灵起、灵起生炅、炅生法明。

周法明横岗山起兵附西梁萧铣，以蒴安㑂黄四州臣于李世民。陶㑆宗亲陶回，回生汪、 汪生敏、敏生陶渊明。陶渊明故里江州寻阳县。即今薪州廣濟县现为湖北省武穴市余川镇陶 家畈。

萧统撰 “时周续之入庐山、事释惠远 [1]，彭城刘遗民亦遁迹匡山，渊明又不征命：谓 之寻阳三隐”。

\section{3. 麻姑献寿匡山考}

麻秋杀符洪、符健杀麻秋。符坚讨东南: 啸咤则五岳推覆; 呼吸则江海绝流。昭武九姓 粟特人, 西郡兰池县, 饮马丈水、筑城万丈湖。 建昌郡。

麻姑 [2]、符宏, 降晋又灭晋。江州刺史朱修之, 寄治匈奴五水蛮, 侨置汝南、弘农、

梁武帝耀武匡山，昭明太子素信三宝。

拜火教天神（摩醌首罗），五品官萨宝惠远，祅祠黄牙寺。

七品令妖 (祅) 人员、建昌永宁道信, 祅正神职北周、隋、唐萨宝府。道信自言: 能绝 粒! 从者众。舔甘露吞仙丹, 兰池城又叫兰绝池城。

太宗三子吴王李恪长寿斋。李君羡国葬灵龟山。建昌郡安甯县流民麻姑、北齐西突厥向 夫人、西梁隋炀帝萧皇后: 已见东海三为桑田天地人三届献寿。 


\section{4. 昭明太子诞生周岁匡山考}

0 岁。南齐永元二年, 雍州刺史萧衍十一月起兵于郭默城; 寨上丁家、丁道迁女丁令光 受孕。

永元三年, 即中兴元年, 三月, 和帝继位江陵, 衍任征东将军。四月, 攻郢城。五月, 夏 候祥中领军和帝车驾竹林寺, 禅房宴衍等群臣。七月, 克郢城。八月丙子, 江州刺史陈伯之以 寻阳县石城降, 退居湖口; 邓元起拥丁令光, 出寨上丁家, 入驻江州寻阳石城。天子遣黄门 郎苏回, 劳军郢城, 衍登舟接驾。

南齐和帝中兴元年, 九月, 萧衍王茂引兵舟楫, 东下江州寻阳县石城临江驿; 萧统诞 生, 寄治襄阳; 侨属南齐和帝雍州建昌郡义阳县双城驿竹林寺禅房即今湖北省武穴市余川镇 匡山旅游风景区竹林寺。

一岁。南齐和帝中兴元年, 九月, 萧统生于寻阳县石城临江驿, 郑绍叔守寻阳寄治襄 阳。

初四衍奉和帝诏, 与陈伯之引兵东下, 抵南豫州克姑熟, 败李居士于新亭。

十月初一，萧统满月，丁令光洗详艾九澡青龙庵。

十二月初六，王珍国张稷杀废帝。初七，衍淫宫、潘妃、余妃、乐不理政。

中兴二年正月, 齐和帝遣席阐文慰劳建康。初九, 宣德太后入宫临朝称制。衍解承制, 䍀潘妃、许余妃王茂, 幸淑媛吴景晖怀孕萧综。

衍, 正月梁公、二月梁王、四月梁武帝。斌和帝、改元天监。五月陈伯之以江州寻阳 郡，降北魏元英。

丁令光怀抱维摩, 周岁江州匡山寺: 庙会伽蓝十八罗汉寺, 颂经鸠摩罗什堂, 夜宿一尖 山峰顶寺，檀越：四海习業齿、弥天释道安。

\section{5. 《昭明文选》成书背景地匡山考}

天监元年五月, 江州太守陈伯之反。天监四年, 《丘迟与陈伯之书》，复归降。

天监十五年, 太子重归故里石城临江驿。访籍贯地雍州竹林寺, 拓夏侯详《围郢城议 帖》，刻《头陀寺碑文》，三十二分《金刚经》。

日出卓木尖、日落卓木寨。

采菊东篱下、悠然望南山。祭陶渊明南山寺。

东进太子洲、菩提流支锄开汉地罗什堂; 西出太子庙、不可思议惠远黄牙寺; 北上伏羲 画卦场、鲍照读书台; 南下彭蟲湖、石门山十八罗汉寺。

《昭明文选》，是一部元嘉三大家：江州刺史刘义庆参军鲍照、江州刺史王羲之重外孙 谢灵运、江州刺史刘柳后军功曹颜延之, 以及竞陵八友谢眺、任昉、沈约, 匡山题材作品 选。

\section{6. 永宁令程名振恩怨匡山考}

隋杨失鼎，天下逐鹿。

破长安：突厥尽虏金银珠宝、宫女民妹，唐王尽收帝都皇城、秦川渭水。

破扬州：宇文化及、窦建德、王世充、处罗可汗，共解隋炀帝萧皇后石榴裙。

破江州: 张善安、周法明、林士弘、尉迟敬德, 争抢江州匡山寺智者大师头炉香。

破瀛州: 刘黑闯杀程名振娇妻老母, 程名振杀刘黑阉片甲不留。

大唐先借突厥兵马、后分突厥东西。

李渊一纸永宁令, 换得程名振十万匈奴五水蛮; 李世民一顶附马帽, 换得周道复详黄安 㑂四州城。

道复、名振, 征西阿史那伏念, 征东高丽平壤城。 
公主绘画仙人湖、太宗撰文灵龟山。五府经略皇亲彭果、彭杲 [3] 下岭南、因沧浪之水 名沧浪书院。

沧浪书院学子, 程务挺, 父名振。

\section{7. 萧皇后突厥汗国匡山考} 展生罗凝。

汝南人周访客居庐江郡寻阳县。访生抚、抚生强、强生灵起、灵起生灵、灵生法展、法

梁州刺史周强同僚雍州刺史萧衍。

直阁将军周灵起共事昭明太子。

江州寻阳周罗睺, 受隋炀帝遣, 讨隋文帝子、晋阳汉王、谅, 阵亡于晋㖓吕三州前线。

又，炅生法尚、法尚生绍范、绍范生道务。江州永安周法尚，隋文帝黄州总管、隋炀帝 金紫光裕大夫、左武卫将军。周绍范, 秦王李世民府库车骑。周道务, 唐太宗附马临川公 主。

萧统有曾孙女萧美娘。皇后隋炀帝、怡妃宇文化及、宠妾窦建德、傧妃处罗可汗、爱妃 颉利可汗、美娘李渊故事...... 。

李靖败突厥。武德四年, 周道务置突厥汗国, 南晋州长吉县土门道。即今武穴市余川镇 彭河村匡山通天河景区头陀寺。

\section{8. 鄂国公炼丹长寿匡山考}

梁武帝普通元年，菩提达摩航海，抵建康；菩提流支，译经来寻阳。

达摩传惠可、惠可传秝、嗓传道信。道信 [4]，禅宗四祖。

净土四祖。智者承惠远，惠远承道安，道安承佛图澄、鸠摩罗什、普提流支，不可思议 人也。

武德四年。道信丈水之源、灵龟山幽居、不知不觉十春秋。惠远万丈湖畔炼丹、晋西 郡、兰池县黄牙寺，两百年。

拜火教妖（祅）人道信, 自言: 能绝粒! 从者众: 武连县公、左武卫将军、值玄武门、五 娘子李君羡, 腾云秦琼捉马港, 驾雾尉迟敬德炼丹房; 江州道行军元帅、天策大将军、秦王 李世民, 耀武匡山九龙城、十八罗汉寺, 扬威萧庄长城、狮子山十八学士、文学馆; 鄂国公 长寿斋延寿十八年。

\section{9. 广东客家始祖彭延年籍贯匡山考}

彭思永知黄州, 迁移鄱阳湖宗族定居彭蟲湖。

彭汝砺知江州, 迁移彭氏宗室定居鄂城大冶。

彭思永 $[5]$, 构云八世孙。构云生滋, 滋生倜、伉、仪, 俱登进士第。进士曾孙, 俱掌 朱梁、后唐刺史印。

思生汝、汝生元、元生念。念公授官朝奉大夫。四十五朝奉公, 辡黄廣匡山彭氏一世 祖。

念生伟、伟生跃; 字忠跃号匡山; 匡山生延年，彭延年广东客家一世祖。

念公又生照, 照名用成、字仁甫, 入籍黄州廣濟县安乐乡二图十甲; 宗亲散布详春安东

乡、罗州城、彭思桥; 用成, 子廷宝, 授金吾卫武略将军。

龟年者念公侄也, 彭震龙者龟年孙也, 文天祥妹婿; 入东关、出西塞、腾挪跌荡彭蟇 湖、金人破黄州以身㚣城。

匡山彭氏，一门三相、五封侯、七进士、九刺史。 


\section{0. 宣和画谱成书匡山考}

宋人议论未定、而兵已渡河。

济南府太守刘豫降金，国号齊、年号阜昌。

彭思永墓葬黄州英山县; 彭汝砺墓葬江州阳新县。大将军彭昱，五子登科，靖远黄河 南、长江北。炼硝配火药、铸铁引火炮、飞车抛火石。

彭门用兵，大好河山取半壁!

汉之匈奴、唐之突厥、宋之辽金。萨宝惠远、祅正道信。周续之、刘遗民、陶洣明, 寻 阳三隐白莲社。

徐铉 [6], 嫁女南唐进士吴淑, 迁蒴州广济县安乐乡吴文村。吴淑有子, 吴遵路; 吴淑 有孙，璞、瑛、琚。

岳飞，诗词歌赋抗金; 秦侩儿孙阵忘抗金; 吴琚宣和书画抗金。

彭蟲湖沧浪书院馆藏《宣和书谱》、《宣和画谱》，是一部由齊国（黄河南、长江北） 大将军彭昱（在北金、南宋之间有一个地方割据独立国，叫齊国。齊国的实际控制人就是彭 昱大将军。) 资助, 舒、蒴、光、黄镇抚使李成主编, 吴琚咙序, 上自魏晋、下止宣和, 以 江州匡山寺周边区域，民族宗教历史文化为题材，集中体现粟特人昭武九姓信仰拜火教人 物、神灵、山川、地理、皇室、庶民等形象特征的绘画史纲。

\section{1. 结论}

自从汉武帝把匈奴金入带到到庐江郡寻阳县，再到宣和年间江淮割据齊国主持编辑书画 索引《宣和书画谱》于江州匡山寺，拜火教在丝绸之路上已经流传了 1226 年。匡山惠远和 寻阳陶渊明弘扬了拜火教西方净土观: 西方有一个极乐世界、人生来世会有一个美好未来。 昭明太子和祅正道信却把拜火教本土化: 提出禅农并重、倡导人间佛教。卫青匈奴铁骑围剿 淮南王刘安、符宏匈奴南迁江州、石虎麻秋筑麻城、萧衍耀武匡山、隋炀帝统一天下、江州 道行军元帅秦王李世民, 无一例外是借助突厥兵马开拓疆土。根据突厥人生活习俗设立突厥 匡州和突厥南晋州, 把拜火教定位国教, 终于在江州匡山寺建立了拜火教远东教廷。《宣和 书画谱》以书画艺术形式真实再现了丝绸之路上拜火教远东教廷遗址江州匡山寺的粟特人建 筑风格、拜火教宗教礼节、西域山川河流和突厥人物形象。

\section{References}

[1] Triple mystery [sui Dynasty].

[2] "Huangzhou History" hongzhi, Ming Dynasty.

[3] He_hongwei Dong_qing. The Chinese national museum of national treasures in the tang dynasty. 2011

[4] "Qizhou History" jiajing, Ming Dynasty.

[5] Peng_kaifu. "Peng Family History” [M]. Jiangxi people's press, 2011

[6] "riding a province" by $\mathrm{xu} \_$hyun, wu_shu 